\title{
Effect of Adsorbed Oxidative Gases on Electrical Properties of Evaporated Films of Phthalocyanines
}

\author{
Yoshihiko SADAOKA*, Yoshiro SAKAI*, Noboru YAMAZOE** \\ and Tetsuro SEIYAMA**
}

\begin{abstract}
The electrical conductivities of phthalocyanines $\left(\mathrm{H}_{2} \mathrm{Pc}, \mathrm{CuPc}, \mathrm{FePc}\right.$ and $\left.\mathrm{CoPc}\right)$ increased with the adsorption of $\mathrm{NO}_{2}, \mathrm{NO}$ and $\mathrm{O}_{2}$. In the thermal desorption spectra of the three gases between room temperature and $300^{\circ} \mathrm{C}$ the first peak appeared in the temperature range $50 \sim 100^{\circ} \mathrm{C}$ for any gas-phthalocyanine system, whereas the second peak in the range $100 \sim 250^{\circ} \mathrm{C}$ were found only on $\mathrm{CoPc}$ and $\mathrm{FePc}$ on which $\mathrm{NO}_{2}$ and $\mathrm{NO}$ had been adsorbed. Although the second peaks involved for far larger amounts of adsorbed gases, the electrical conductivities were found to be mostly affected by the gas adsorption responsible for the first peaks. The carrier (hole) may be produced by the interaction of ligand parts of phthalocyanine with $\mathrm{NO}_{\mathrm{x}}$ and $\mathrm{O}_{2}$.
\end{abstract}

\section{Introduction}

It is well-known that ambient gases exert influence on the semiconductive properties of a number of organic compounds. The electrical conductivities of $\beta$-carotene ${ }^{1)}$, metal-free phthalocyanine $\left(\mathrm{H}_{2} \mathrm{Pc}\right)^{2)}$ and anthracene ${ }^{3)}$, for example, increase with the adsorption of electron acceptor type gases. Because of such gas-sensitive properties, phthalocyanines are being received interest as sensing material for detecting ambient gases $^{4,5}$. We have reported ${ }^{6,7)}$ that some phthalocyanines are very sensitive to oxidative gases such as $\mathrm{O}_{2}, \mathrm{NO}$ and $\mathrm{NO}_{2}$, Despite extensive investigations published to date, however, the nature of gas adsorption on phthalocyanines have not been fully understood.

Metal phthalocyanine molecules have two possible sites for gas adsorption, i.e., the central metal ions and the ligand $\pi$-electron systems. It has not been known on which sites gas molecules are actually adsorbed. It seems that the chemical properties of the two sites may change considerably depending on the central ions. Wolberg and Manassen" have reported that in the electrochemical oxidation of iron and cobalt phthalocyanine ( $\mathrm{FePc}$ and $\mathrm{CoPc}$ ) the central metal ions are more easily oxidized than the

\footnotetext{
* Faculty of Engineering, Ehime University (Bunkyocho, Matsuyama, Ehime)

** Department of Materials Science and Technology, Graduate School of Engineering Sciences, Kyushu University (Hakozaki, Higashiku, Fukuoka)

Key Words: $\mathrm{NO}_{2}$ Sensor, Phthalocyanine, Electrical Conductance of Phthalocyanine
}

ligand $\pi$-electron system, while in the case of copper and hydrogen phthalocyanine (CuPc and $\mathrm{H}_{2} \mathrm{Pc}$ ) the ligand part are oxidized. Such differences in chemical properties may be reflected on the adsorption properties of phthalocyanines toward oxidative gases.

In the present work, we have investigated the adsorption of $\mathrm{NO}_{2}, \mathrm{NO}$ and $\mathrm{O}_{2}$ on four phthalocyanines $\left(\mathrm{H}_{2} \mathrm{Pc}, \mathrm{CuPc}, \mathrm{CoPc}\right.$ and $\left.\mathrm{FePc}\right)$ by means of thermal desorption technique and infrared spectroscopy. Efforts were concentrated especially on differentiating adsorption states and adsorption sites as well as on revealing how the respective adsorption states affect the electrical conductivities of phthalocyanine films.

\section{Experimental}

For electrical conductivity measurements, surface-type cells were prepared by vacuum evaporation $^{\text {") }}$ Each phthalocyanine $\left(\mathrm{H}_{2} \mathrm{Pc}, \mathrm{CuPc}\right.$, $\mathrm{CoPc}$ or $\mathrm{FePc}$ ) of $\alpha$-form were deposited by vacuum evaporation from a Pyrex crucible onto a glass substrate $\left(1 \times 1 \mathrm{~cm}^{2}\right)$. The film obtained was transformed into $\beta$-phthalocyanine by heating at $350^{\circ} \mathrm{C}$ for $30 \mathrm{~min}$ under a nitrogen atmosphere. Then, two gold electrodes, separated by $200 \mu \mathrm{m}$ from each other, were deposited over the film. Electrical measurements were carried out with an electrometer (Takeda Riken, model TR 8651) and a d.c. power supply.

Thermal desorption spectra were obtained with $\beta$-form phthalocyanine powder $(0.3 \mathrm{~g})$ by means of a Pirani vacuum gauge (Nihonshinku, model GP-2 T) and/or a quadrupole mass spectrometer 
(Nihonshinku, model SM $800 \mathrm{~A}$ ) which was connected to the sample tube through a capillary. After heat-treatment $\left(150 \sim 250^{\circ} \mathrm{C}\right)$ under evacuation, the sample was exposed to $\mathrm{O}_{2}, \mathrm{NO}$ or $\mathrm{NO}_{2}(20 \sim 200$ Torr $)$ at room temperature. After evacuating to ca. 0.1 Torr or below, the sample was then heated up to $300^{\circ} \mathrm{C}$ at a constant rate under evacuation to record thermal desorption spectra. The gases used were of commercial origin (Takachiho); the purities of $\mathrm{NO}$ and $\mathrm{NO}_{2}$ were $99.9 \%$ and $99.5 \%$, respectively. Infrared spectra were recorded on a double beam spectrometer (JASCO model IR$\mathrm{G}$ ), by using $\beta$-form phthalocyanine films evaporated on $\mathrm{KBr}$ plates.

\section{Results and Discussion}

\subsection{Thermal desorption spectra}

Thermal desorption spectra for $\mathrm{O}_{2}, \mathrm{NO}$, and $\mathrm{NO}_{2}$ were measured by using $\beta$-form phthalocyanines $\left(\mathrm{H}_{2} \mathrm{Pc}, \mathrm{CuPc}, \mathrm{CoPc}\right.$ and $\left.\mathrm{FePc}\right)$. In each case, gas desorption went to completion below $300^{\circ} \mathrm{C}$. The spectra, however, were found to change characteristically depending on the central metal ion of the phthalocyanines. With $\mathrm{CoPc}$ and $\mathrm{FePc}$, the spectra for $\mathrm{O}_{2}$ gave a single desorption peak which appeared in the range $50 \sim 100^{\circ} \mathrm{C}$, whereas that of $\mathrm{NO}$ or $\mathrm{NO}_{2}$ gave double peaks in the range $50 \sim 100^{\circ} \mathrm{C}$ and $100 \sim$ $250^{\circ} \mathrm{C}$. In the latter case, desorption spectra were also recorded on a mass spectrometer to analyse desorbed gases. The partial pressures of $\mathrm{NO}_{2}(\mathrm{~m} / \mathrm{e} \mathrm{46}), \mathrm{N}_{2} \mathrm{O}(\mathrm{m} / \mathrm{e} 44)$, and $\mathrm{NO}(\mathrm{m} / \mathrm{e}$ 30) thus monitored are shown in Fig. $1^{* 1}$. Following NO adsorption, only NO was detected over the two desorption peaks. This means that $\mathrm{NO}$ is reversibly adsorbed. Following $\mathrm{NO}_{2}$ adsorption, however, the situation was more complex. In addition to the desorption of $\mathrm{NO}_{2}$ which took place in the ranges $50 \sim 100^{\circ} \mathrm{C}$ and $100 \sim 250^{\circ} \mathrm{C}$. NO and $\mathrm{N}_{2} \mathrm{O}$ were also found in the desorbed gas. The desorption of NO gave a chromatogram which was essentially the same as one obtained when NO was adsorbed. The $\mathrm{N}_{2} \mathrm{O}$ desorption became significant above $150^{\circ} \mathrm{C}$. These results show that a part of $\mathrm{NO}_{2}$ undergo chemical changes to $\mathrm{NO}$ and $\mathrm{N}_{2} \mathrm{O}$. The IR

*1 The relative sensitivity and the cracking pattern coefficient were used to estimate the partial pressure of each component.

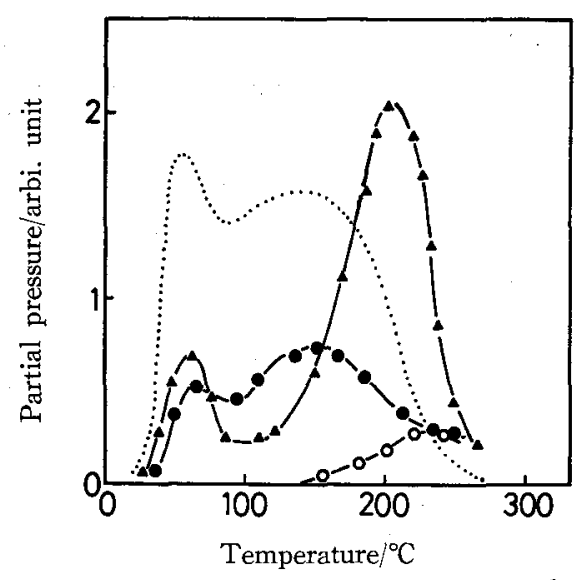

Fig. 1 Desorption spectra for $\mathrm{NO}_{\mathrm{x}}$ adsorbed on $\mathrm{CoPc}$

Heating rate: $10^{\circ} \mathrm{C} / \mathrm{min}$, Pressure of adsorption: 150 Torr (NO), 50 Torr $\left(\mathrm{NO}_{2}\right)$, (…) $\mathrm{m} / \mathrm{e} 30$ for $\mathrm{NO}$ adsorption, (A) $\mathrm{m} / \mathrm{e} 46$, (O) $\mathrm{m} / \mathrm{e} 44$, (O) $\mathrm{m} / \mathrm{e} 30$ for $\mathrm{NO}_{2}$ adsorption

studies described later revealed that the adsorbed $\mathrm{NO}_{2}$ on phthalocyanines exists as various types of adsorbates. It is considered that $\mathrm{NO}$ was formed from $\mathrm{NO}_{2}$ in the course of adsorption while $\mathrm{N}_{2} \mathrm{O}$ was formed by thermal decomposition of some adsorbates. Anyway, it is evident that $\mathrm{NO}$ and $\mathrm{NO}_{2}$ are adsorbed on $\mathrm{CoPc}$ in at least two states, which are responsible for the occurrence of two desorption peaks.

In contrast, quite different chromatograms were obtained with $\mathrm{CuPc}$ and $\mathrm{H}_{2} \mathrm{Pc}$; desorption spectra after the adsorption of any of $\mathrm{O}_{2}, \mathrm{NO}$ and $\mathrm{NO}_{2}$ invariably showed only a single desorption peak in the temperature range $50 \sim 100^{\circ} \mathrm{C}$. Desorption spectra for $\mathrm{NO}_{2}$ adsorbed on $\mathrm{H}_{2} \mathrm{Pc}$ is shown in Fig. $2^{* 1}$. $\mathrm{NO}_{2}$ and $\mathrm{N}_{2} \mathrm{O}$ were found in the desorbed gas with the ratio of desorbed $\mathrm{N}_{2} \mathrm{O}$ to $\mathrm{NO}_{2}$ being $c a .0 .08$ while that of desorbed $\mathrm{NO}$ and $\mathrm{N}_{2} \mathrm{O}$ to $\mathrm{NO}_{2}$ in $\mathrm{CoPc} c a .0 .3$ and $c a .0 .1$, respectively.

Table 1 summarizes the temperature $\left(T_{\mathrm{m}}\right)$ at which the thermal desorption rate became maximum in each gas-phthalocyanine system. Obviously, the desorption in the lower temperature region $\left(50 \sim 100^{\circ} \mathrm{C}\right.$, first peak) is common to all systems, while that in higher temperature region $\left(100 \sim 250^{\circ} \mathrm{C}\right.$, second peak) is unique to the combinations between $\mathrm{NO}$ and $\mathrm{NO}_{2}$ and $\mathrm{CoPc}$ and FePc. Such a difference among the 


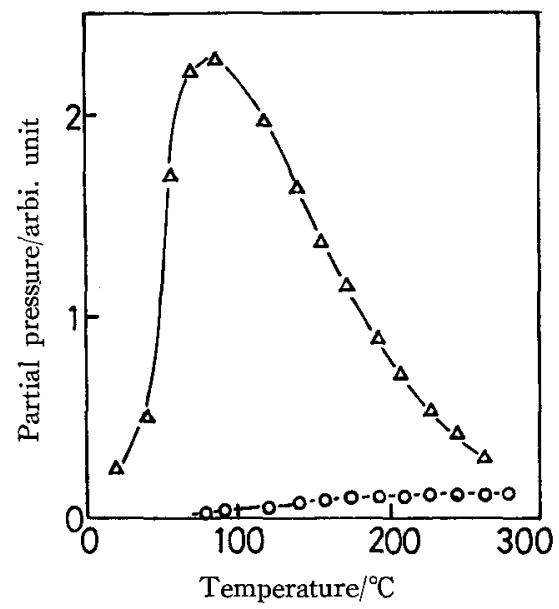

Fig. 2 Desorption spectra for $\mathrm{NO}_{2}$ adsorbed on $\mathrm{H}_{3} \mathrm{Pc}$

Heating rate: $10^{\circ} \mathrm{C} / \mathrm{min}$, Pressure of adsorption: 60 Torr, $(\Delta) \mathrm{m} / \mathrm{e} 46,(O) \mathrm{m} / \mathrm{e}$ 44

Table 1 Temperature of the peaks on desorption spectra

\begin{tabular}{l|r|r|r}
\hline & \multicolumn{3}{|c}{$T_{\mathrm{m}} /{ }^{\circ} \mathrm{C}$} \\
\cline { 2 - 4 } & $\mathrm{O}_{2}$ & $\mathrm{NO}$ & $\mathrm{NO}_{2}$ \\
\hline $\mathrm{H}_{2} \mathrm{Pc}$ & 53 & 53 & 82 \\
$\mathrm{CuPc}$ & 63 & 77 & 57 \\
$\mathrm{CoPc}$ & 75 & 69 & 83 \\
& & 130 & 200 \\
$\mathrm{FePc}$ & 63 & 63 & 63 \\
& & 130 & 200 \\
\hline
\end{tabular}

Heating rate: $10^{\circ} \mathrm{C} / \mathrm{min}$

gas-phthalocyanine systems seems to be related to the oxidation potential of the central metal ion. As stated earlier the central metal ions of $\mathrm{FePc}$ and $\mathrm{CoPc}$ are oxidized more easily than those of other phthalocyanines ${ }^{8)}$. We consider that the second peaks in $\mathrm{FePc}$ and $\mathrm{CoPc}$ are ascribed to the desorption of $\mathrm{NO}$ and $\mathrm{NO}_{2}$ which are adsorbed oxidatively on the central metal ions. Gas adsorption on the central metal ions have been proposed by Ercolani and Neri ${ }^{92}$ and Mochida et al. ${ }^{10)}$ in NO-phthalocyanine systems. In the present study with $\mathrm{FePc}$ and $\mathrm{CoPc}, T_{\mathrm{m}}$ of the second desorption peak for NO $\left(130^{\circ} \mathrm{C}\right)$ is significantly lower than that for $\mathrm{NO}_{2}\left(200^{\circ} \mathrm{C}\right)$. This suggests that $\mathrm{NO}_{2}$ is bonded to the metal ions more strongly than $\mathrm{NO}$, as expected from the order of electron affinity,
$\mathrm{NO}_{2}>\mathrm{NO}$.

On the other hand, the first desorption peaks $\left(50 \sim 100^{\circ} \mathrm{C}\right)$ may be ascribed to adsorbates bounded to the ligand parts of phthalocyanines, not to metal ions. In order to confirm this assumption, the number of adsorbed molecules per unit weight of phthalocyanines $N_{\text {ad }}$ for each gasphthalocyanine system was estimated from an increase in pressure when the sample was heated up to $250^{\circ} \mathrm{C}$ in a closed system. The partial decomposition of $\mathrm{NO}_{2}$ to $\mathrm{NO}$ and $\mathrm{N}_{2} \mathrm{O}$ was neglected in this estimation. The results are shown in Table 2, where the value for $\mathrm{N}_{2}$ under cor-

Table 2 The number of adsorbed molecules per unit weight of phtholocyanine $\left(N_{\mathrm{ad}}\right)$

\begin{tabular}{c|c|c|c|c}
\hline & \multicolumn{4}{|c}{$\left(N_{\mathrm{ad}} /\right.$ molecule $\left.^{-1}\right) \times 10^{-9}$} \\
\cline { 2 - 5 } & $\mathrm{N}_{2}$ & $\mathrm{O}_{2}$ & $\mathrm{NO}$ & $\mathrm{NO}_{2}$ \\
\hline $\mathrm{H}_{2} \mathrm{Pc}$ & 1 & 0.5 & 1 & 3 \\
$\mathrm{CuPc}$ & 3 & 1 & 2 & 6 \\
$\mathrm{CoPc}$ & 0.5 & 1 & 20 & 40 \\
$\mathrm{FePc}$ & 1 & 2 & 30 & 40 \\
\hline
\end{tabular}

responding conditions is also included for comparison. As seen from this table, $N_{\text {ad }}$ remains small for the cases where only the first desorption peaks appears, being comparable to that of $\mathrm{N}_{2}$ adsorption. In contrast, $N_{\mathrm{ad}}$ is larger for $\mathrm{NO}$ and $\mathrm{NO}_{2}$ on $\mathrm{CoPc}$ and $\mathrm{FePc}$ in which both desorptions participate; the molar ratio of the adsorbed $\mathrm{NO}+\mathrm{NO}_{2}$ to $\mathrm{CoPc}$ or $\mathrm{FePc}$ is estimated to be ca. $0.2 \sim 0.3$ or 0.4 , respectively. In these systems, the desorption energies of $\mathrm{O}_{2}$, $\mathrm{NO}$, and $\mathrm{NO}_{2}$ obtained from thermal desorption spectra were much larger than the heats of condensation. Such an estimation leads to a picture that the adsorbates responsible for the first desorption peak are weakly bonded to the ligand parts of phthalocyanine, while those (NO and $\mathrm{NO}_{2}$ ) responsible for the second peaks are bounded to the central ions ( $\mathrm{Co}$ and $\mathrm{Fe}$ ).

\section{$3.2 I R$ spectra}

The adsorption states of $\mathrm{NO}_{2}$ on phthalocyanines were investigated by $I R$ spectroscopy. As shown in Fig. 3, when $\mathrm{NO}_{2}$ was adsorbed at room temperature on $\mathrm{CoPc}$ and $\mathrm{CuPc}, I R$ bands responsible to adsorbates appeared at; $1590,1510,1460,1400,1333^{* 2}, 1265,1050$ and 

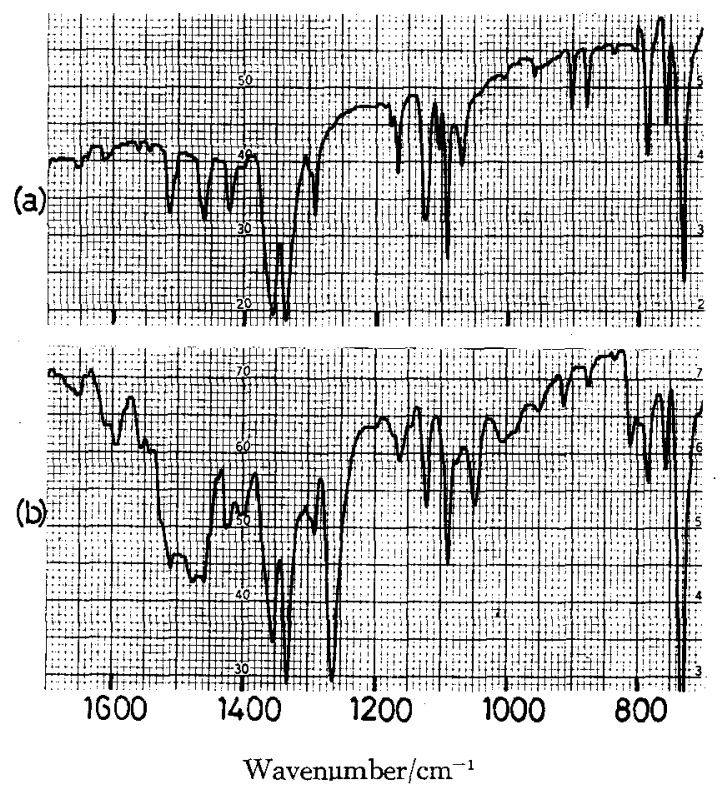

Fig. 3 Infrared spectra for $\mathrm{NO}_{2}$ adsorbed phthalocyanine

Pressure of adsorption: 50 Torr, (a) $\mathrm{CuPc}$, (b) $\mathrm{CoPc}$

$1005 \mathrm{~cm}^{-1}$ for $\mathrm{CoPc}, 1460$ and $1333 \mathrm{~cm}^{-1 * 2}$ for $\mathrm{CuPc}$ (the other bands observed in Fig. 3 are ascribed to the phthalocyanine substrate). With reference to the literature ${ }^{11}$, these bands could be assigned to various forms of adsorbates consisting of $\mathrm{NO}, \mathrm{NO}_{2}$, and $\mathrm{NO}_{3}$ groups as listed in Table 3. To know the thermal behavior of

Table $3 I R$ bands of phthalocyanine- $\mathrm{NO}_{2}$

\begin{tabular}{c|ll}
\hline \hline Wavenumber $/ \mathrm{cm}^{-1}$ & \multicolumn{2}{c}{ form } \\
\hline 1590 & $\mathrm{M}-\mathrm{NO}$ & nitrosyl and/or \\
& $\mathrm{M}<\mathrm{O}_{>}^{-}>\mathrm{NO}$ & nitrato bidentate \\
1510,1005 & $\mathrm{M}-\mathrm{O}-\mathrm{NO}_{2}$ & nitrato monodentate \\
1460 & $\mathrm{M}-\mathrm{O}-\mathrm{NO}$ & nitrito \\
1400,1050 & $\mathrm{NO}_{3}^{-}$ & free ion \\
1265 & $\mathrm{NO}_{2}^{-}$ & free ion \\
\hline
\end{tabular}

these adsorbates, the samples were heated stepwise up to $300^{\circ} \mathrm{C}$ at $50^{\circ} \mathrm{C}$ intervals in vacuo, with a heating period of $10 \mathrm{~min}$ at each temperature. The results are shown in Fig. 4. On CuPc, the bands at 1460 (nitrito) and 1333 $\mathrm{cm}^{-1}$ (nitro) disappeared below $100^{\circ} \mathrm{C}$ in agree-

*2 The strong absorption band centered at $1333 \mathrm{~cm}^{-1}$ was also observed in phthalocyanine substrate.

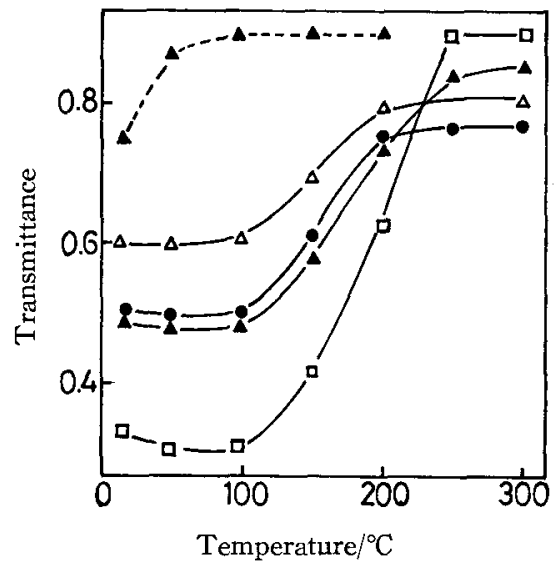

Fig. 4 Variation of transmittance of each band in vacuo with heat-treatment temperature

Pressure of adsorption: 50 Torr, (-- --$)$ $1460 \mathrm{~cm}^{-1}$, for $\mathrm{CuPc},(-\bigcirc-) 1510 \mathrm{~cm}^{-1}$, (-A一) $1460 \mathrm{~cm}^{-1},(-\triangle-) 1400 \mathrm{~cm}^{-1}$, (一- $1265 \mathrm{~cm}^{-1}$ for $\mathrm{CoPc}$

ment with the results of the thermal desorption experiments. On $\mathrm{CoPc}$, heat-treatments up to $100^{\circ} \mathrm{C}$ have little or no effects on the band intensities. The bands at 1590, 1510, 1400, 1333, 1050 and $1005 \mathrm{~cm}^{-1}$, assignable to nitrosyl, nitrato, nitro or free $\mathrm{NO}_{3}$, disappeared between 100 and $200^{\circ} \mathrm{C}$, whereas those at 1460 and 1265 $\mathrm{cm}^{-1}$, characteristics of nitrito or free $\mathrm{NO}_{2}^{-}$, disappeared between 100 and $250^{\circ} \mathrm{C}$. Judging from the desorption temperature, these adsorbates should be ascribed to the second peaks of the thermal desorption chromatograms.

\subsection{Electrical conductivity}

The electrical conductance $(G)$ of pure phthalocyanine films after evacuation at $300^{\circ} \mathrm{C}$ was found to obey an exponential law in the temperature range $50 \sim 280^{\circ} \mathrm{C}$

$$
G=G_{\mathrm{o}} \exp (-E / k T)
$$

where $E$ is the activation energy and $G_{0}$ the preexponential factor. The effects of gas adsorption on conductance were investigated by exposing the films to $\mathrm{O}_{3}, \mathrm{NO}$, and $\mathrm{NO}_{2}$ at room temperature followed by heating up to $300^{\circ} \mathrm{C}$ at a constant rate in vacuo. The results on $\mathrm{H}_{2} \mathrm{Pc}$ and $\mathrm{CoPc}$ are shown in Figs. 5 and 6. The conductance of the films increased rapidly (within a minute) on exposure to the gases and decreased slightly on subsequent evacuation at 


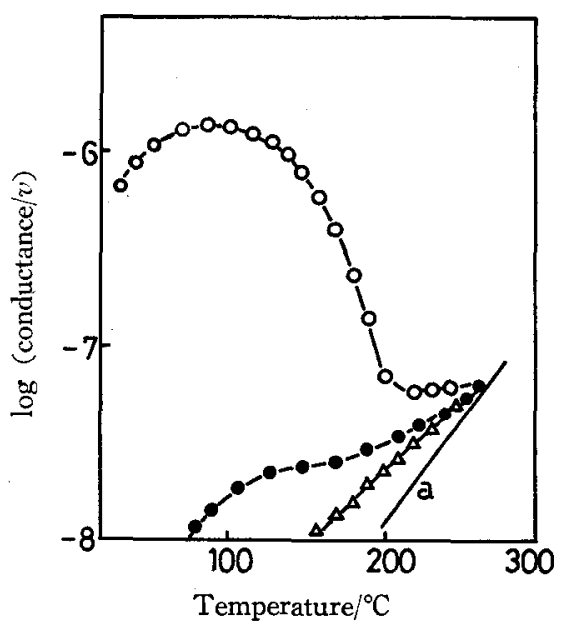

Fig. 5 Temperature dependence of conductance of $\mathrm{H}_{2} \mathrm{Pc}$ in vacuo

Heating rate: $10^{\circ} \mathrm{C} / \mathrm{min}$, Adsorbed gas:

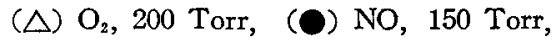
(O) $\mathrm{NO}_{2}, 50$ Torr, (a) after heating up to $300^{\circ} \mathrm{C}$

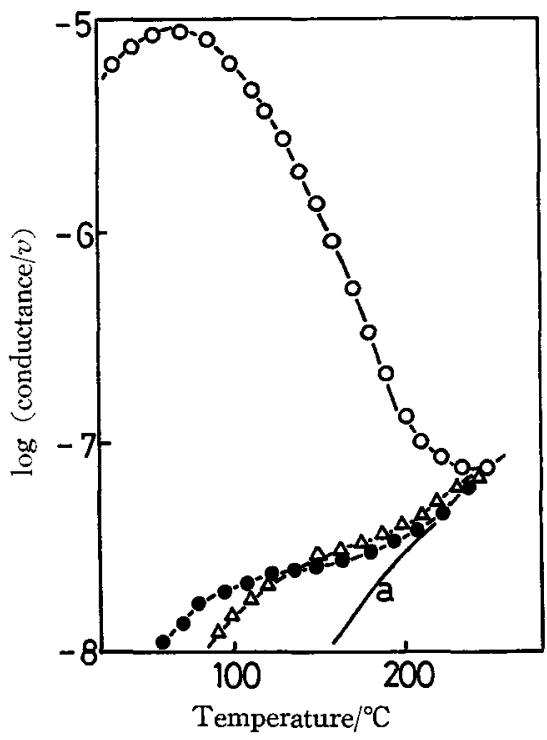

Fig. 6 Temperature dependence of conductance of $\mathrm{CoPc}$ in vacuo

Heating rate: $10^{\circ} \mathrm{C} / \mathrm{min}$, Adsorbed gas: $(\triangle) \mathrm{O}_{2}, 200$ Torr, (O) NO, 150 Torr, (O) $\mathrm{NO}_{2}, 50$ Torr, (a) after heating up to $300^{\circ} \mathrm{C}$

room temperature. As seen from the figures, $\mathrm{NO}_{2}$ exerts far more extensive influences on the conductance their $\mathrm{NO}$ or $\mathrm{O}_{2}$ does. It is noted that when $\mathrm{NO}_{2}$ is adsorbed the conductance of $\mathrm{H}_{2} \mathrm{Pc}$ becomes ca. 10 times as large as that of
CoPc, although the amount of $\mathrm{NO}_{2}$ adsorption is far less on $\mathrm{H}_{2} \mathrm{Pc}$ than on $\mathrm{CoPc}$ as described previously. This indicates that the conductance of the films cannot simply be correlated with the amount of adsorbed gas.

With raising temperature up to $300^{\circ} \mathrm{C}$ in vacuo, the conductance went through a maximum. The most marked extremes were exhibited by the films on which $\mathrm{NO}_{2}$ had been adsorbed. Such temperature dependences are of course associated with the thermal desorption of gases from the films. For the $\mathrm{NO}_{2}$-adsorbed $\mathrm{H}_{2} \mathrm{Pc}$, a steep decrease in conductance took place in the medium temperature range $\left(50 \sim 200^{\circ} \mathrm{C}\right)$, which coincided with the thermal desorption range of adsorbed $\mathrm{NO}_{2}$ (Fig. 2). In the case of $\mathrm{NO}_{2}$-adsorbed $\mathrm{CoPc}$, however, the conductance decreased in the similar temperature range, while the main desorption peak (second peak) appeared in the still higher temperature range (Fig. 1). The discrepancy of the two temperature ranges shows that the $\mathrm{NO}_{2}$ adsorbates bonded to $\mathrm{Co}$ ions, which are responsible for the second desorption peak as mentioned earlier, do not affect the conductance significantly. In stead the $\mathrm{NO}_{2}$ adsorbates bonded to the ligand parts are considered to be mainly associated with the conductance changes.

It has been reported ${ }^{6,7)}$ that the change in conductivity with gas concentration is interpretable on an extrinsic conduction model in which oxidative gas adsorption introduces an electron acceptor lavel in $p$-type phthalocyanine. For simplicity, it is assumed in the following discussion that hole mobility is not affected by gas adsorption, then the carrier (hole) concentration, $p$ is given by,

$$
p=\left(2 N_{\mathrm{v}} N_{\mathrm{a}}\right)^{1 / 2} \exp \left(-E_{\mathrm{a}} / k T\right) \propto G
$$

where $N_{\mathrm{v}}$ is the effective density of states in valence band, $N_{\mathrm{a}}$ the acceptor density and $E_{\mathrm{a}}$ the activation energy. $p$ is expected to increase with an increase in amount of adsorbed oxidative gases as well as with a decrease in oxidation potential of phthalocyanines. For gasphthalocyanine systems two mechanisms of hole creation may be considered: i) oxidation of central ions ( $\mathrm{Me}$ (II) $\mathrm{Pc} \longrightarrow \mathrm{Me}$ (III) $\mathrm{Pc}$ ) and ii) oxidation of ligand ( $\mathrm{Pc} \longrightarrow \mathrm{Pc}^{+}$(cation radical)). As mentioned earlier, oxidation potential of the metal ions in $\mathrm{CoPc}$ and $\mathrm{FePc}$ is lower than that 
of the ligand parts, whereas the ligand parts are oxidized in $\mathrm{CuPc}$ and $\mathrm{H}_{2} \mathrm{Pc}$. If the hole creation due to gas adsorption should occur by metal oxidation for $\mathrm{CoPc}$ and $\mathrm{FePc}$ and by ligand oxidation for $\mathrm{H}_{2} \mathrm{Pc}$ and $\mathrm{CuPc}, p$ should be larger for $\mathrm{CoPc}$ and $\mathrm{FePc}$ than for $\mathrm{H}_{2} \mathrm{Pc}$ and $\mathrm{CuPc}$ in the temperature range below ca. 200 ${ }^{\circ} \mathrm{C}$, because the number of adsorbed $\mathrm{NO}_{2}$ molecule on $\mathrm{CoPc}$ and $\mathrm{FePc}$ are much larger than that on $\mathrm{H}_{2} \mathrm{Pc}$ and $\mathrm{CuPc}$. On the contrary, if holes are created by ligand oxidation for all phthalocyanines, one can expect that $p$ is larger for $\mathrm{H}_{2} \mathrm{Pc}$ and $\mathrm{CuPc}$ than for $\mathrm{CoPc}$ and $\mathrm{FePc}$, because the ligand oxidation potential is smaller for $\mathrm{H}_{2} \mathrm{Pc}$ and $\mathrm{CuPc}$ than for $\mathrm{CoPc}$ and $\mathrm{FePc}$ while the numbers of adsorbed $\mathrm{NO}_{2}$ corresponding to the first peak are comparable in all samples. In fact, it has been confirmed in the present study that $\mathrm{H}_{2} \mathrm{Pc}$ and $\mathrm{CuPc}$ show larger conductance than $\mathrm{CoPc}$ and $\mathrm{FePc}$ when $\mathrm{NO}_{2}$ is adsorbed. These results indicate that the enhancement of conductance resulting from gas adsorption can mainly be attributed to the $\mathrm{NO}_{2}$ molecules weakly adsorbed on the ligand parts but not to those attached on metal ions having a vacant $d_{z}^{2}$ orbital.

Adsorbed $\mathrm{NO}_{2}$ molecules on the ligand parts may act as a $\pi$-electron acceptor, and the in- duced positive holes may wander by the resonance among the neighboring molecules.

The effect of $\mathrm{NO}$ or $\mathrm{O}_{2}$ on conductivity was much smaller than that of $\mathrm{NO}_{2}$. This difference in gas sensitivity corresponds well to the difference in electron affinity, $\mathrm{NO}_{3}>\mathrm{NO}$ and $\mathrm{O}_{2}$, as described in the previous paper ${ }^{6,7)}$.

\section{References:}

1) TH.G.J. Van Oirschot, D. Van Leeuwen and J. Medema, J. Electroanal. Chem. 37, 373 (1972).

2) N.I. Ionescu and P. Banyai, Rev. Roum. Chim. 24, 669 (1979).

3) W.G. Schneider and T.C. Waddington, J. Chem. Phys. 25, 358 (1956).

4) N.I. Ionescu and P. Banyai, Rev. Roum. Chim. 24, 267 (1979).

5) V.F. Kiselev, V.V. Kurylev and N.L. Levshin, phys. stat. sol. (a) 42, K 61 (1977).

6) Y. Sadaoka, N. Yamazoe, and T. Seiyama, Denki Kagaku 46, 597 (1978).

7) Y. Sadaoka, Y. Sakai, I. Aso, N. Yamazoe and T. Seiyama, Denki Kagaku 48, 486 (1980).

8) A. Wolberg and J. Manassen, J. Amer. Chem. Soc. 92, 2982 (1970).

9) C. Erocolani and C. Neri, J. Chem. Soc., (A), 1715 (1967).

10) I. Mochida, K. Takeyoshi, H. Fujitsu and K. Takeshita, J. Mol. Catal. 3, 417 (1977/78).

11) K. Nakamoto, "Infrared spectra of inorganic and coordination compounds", John Wiley and Sons, Inc., New York (1970).

(Received Oct. 1, 1981; Accepted Dec. 28, 1981)

\title{
《本会刊行図曹案内〉
}

\section{半導体・集積回路技術シンポジゥム＼cjkstart講演論文集＜第 3 集 >}

\author{
電気化学協会電子材料委員会編 B 5 判 集録論文 77 件 本文 462 ページ 頒布価格 1 部 6,000円（送料 400 円）
}

约本シンポジっム注，毎年春秋 2 回，関連学協会の協賛を得て，材料・プロセス・デバイス・評価と広範囲に亘り，貴重な発表と活 発な討論を重ねて，研究者・技術者諸氏のテクノロジの相互理解を果してきました。

将来の技術革新は，今日までの長い關の技術の蓄積によるところ大であります。本シンポジャムのこれまでの講演論文ををとめ 第 1 回から 10 回までの分を「第 1 集」ささらら第 11 回から 15 回までの分を「第2集」として刊行しましたが，今回その「第 3 集」として第 16 回 (1979 年 5 月) から第 20 回 (1981 年5月) までの分をまとめて，その内容についてより技術的に参考にし 易い上う分類・再編集して刊行することになりました。本講演論文集が，今後この方面の研究・開発・生産を志す人々にとって も，またそれぞれの尃門分野に携わっている人々にとっても良く参考になれば仵いであります，なお，各集とも部数が限定されて いますので吅早目に和申し込み下るい.

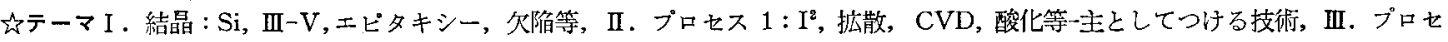

ス 2 : Etching, 微細加工等主としてとる技術，IV，デペイス：素子の構造，製法，特性等，V. 組立・䒠装：Bonding, 多層配

線, パッケージ等, VI. 解析・評価 : 材料解析, 評価, 測定等

败第 1 集 ( 2 分冊) 第 1 回（1971 年 10 月）－第 10 回（1976 年 5 月）の分

集録論文 187 件・本文 870 ページ 頒布価格：1部 9,500 円（送料 600 円）

㘧第 2 集第 11 回 (1976 年 11 月) 第 15 回(1978 年 11 月)の分

集録論文 91 件・本文 540 ベージ 頒布価格：1 部 5,000 円（送料 400 円）

ち申込先 送本先を明記し，代金を添えて (現金書留)，下記宛打申し込子下さい。

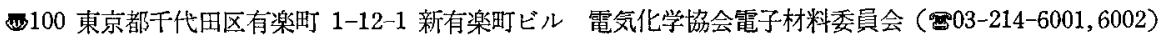

